\title{
Innovative Dominants of Strategic Control and Continuous Improvement: the Quality and Quantity Imperative
}

\author{
Lidiia Karpenko \\ Department of the Economic \\ and Financial Policy, \\ Odessa Regional Institute for Public \\ Administration of the National Academy \\ under the President of Ukraine, \\ Odessa, Ukraine \\ Lidiiako888@gmail.com \\ http://orcid.org/0000-0002-2888-2477 \\ Pavlo Kukhta \\ Department of Management \\ of Innovation and Investment Activities, \\ Taras Shevchenko National University \\ of Kyiv, Ukraine \\ kukhta@knu.ua \\ http://orcid.org/0000-0002-0312-8128
}

\author{
Pavlo Voronzhak. \\ Department of Tax Policy, \\ University of the State Fiscal Service \\ of Ukraine, \\ Irpin, Ukraine \\ vorongak@gmail.com \\ http://orcid.org/0000-0001-9427-7905
}

\author{
Vasyl Zalizko \\ Researcher of Faculty of Economics, \\ Taras Shevchenko National University of \\ Kyiv, \\ Kyiv, Ukraine \\ Lidako@list.ru \\ http://orcid.org/0000-0001-5362-827
}

\begin{abstract}
This paper investigates the innovative dominants of strategic control and continuous improvement on the base of the quality and quantity imperative in the coordinates of globalization changes and European integration. The conceptual bases for the development of strategic planning programs in international business are examined, such as: monitoring strategic thrusts or projects, the develop of customer orientation, systematization examples of ways customer value across business processes in several functions. Components of the methodological basis of the strategy process of the activation of enterprises innovation and investment development, the formation of its conceptual model, and the implementation of strategic control are proposed and justified. In the article authors investigate two main types of the realization functional control: monitoring of strategic programs, analysis and optimization of strategy sectors. The objective of research consists in defining the quality and quantity imperative regarding strategy control.
\end{abstract}

Keywords - strategic control, imperative, implementation control, customer orientation, functional control. monitoring of strategic programs.

\section{INTRODUCTION}

The development of domestic enterprises in the modern realities of time requires the application of systematic approach to the construction of strategy for the operation and further genesis which are enterprises aimed at the economic result, to strengthen their own competitive positions in the market. The successful activity of the company involves the need for a thorough study of the market environment, logistics, innovation and investment policy, changes in the product range, flexible pricing policy, restructuring of the organizational structure of management, the formation of a new philosophy of relations with contractors. European management practice has shown that the greatest popularity of developed countries and the leading indicators of gross domestic product per capita are the respect of strategic management tools, strategic control and administration attitudes, their mission definition and adaptation, and modern managerial innovations at enterprises.

A peculiar catalyst for the economic development of any country is strategy development and investment policy. The investment process is considered as a vector of strategic development and forms the basis for successful socioeconomic development of the state and its regions. The intensification of investment processes and the effective increase of investment volumes are important factors in carrying out structural reforms in the economy and implementing an innovation-investment model of development in Ukraine [1]. Today the methodological platform of the integrated innovative dominants strategic control and continuous improvement on the base of the quality and quantity imperative is one of the main task strategy administration and management.

The analysis of indicators of the innovative process of the balanced system is an integral part of the analysis of indicators of internal business processes, which involves a comprehensive study of strategic innovation aspects of the enterprise's business. The organization of strategic management of innovation activities based on a balanced system of indicators and results of applied strategic analysis 
consists of forming the innovation component of the strategic indicators system and analyzing the indicators included in it, which forms quantitative and qualitative imperatives of the organization's strategic control. At the same time, however, it is necessary to take into account that the innovation component, in turn, is an element of the internal business processes of the balanced scorecard, since the innovation process is one of the business processes along with the operational and after-sales service [2;3].

\section{LITERATURE REVIEW}

Research of strategy development, strategy control, investment activity, innovation potential production, its structure and methods for evaluation, innovation investment into enterprises development was conducted in the studies by foreign and Ukrainian scientists. For example, Karpenko L., Pashko P., Voronzhak P., Kalach H., and Nazarov M., present the results regarding formation of the system of fair businesspractice of the company under conditions of corporate responsibility [8]. Fabozzi F. explores investment management [4]. Authors like Elton E., Gruber M., Brown $\mathrm{S}$. and Goetzmann W. investigate the question of modern portfolio theory and investment analysis [3]. Piarce J., for instant, had dedicated his works to strategic management, formulation, implementation, and control [7]. Frankova S. has special interest for studding of instruments for innovation support and their classification which are used in european countries [11]. Karpenko L. and Voronzhak P. are working on the issues of base alternatives and the paradigm of impact investing development in the coordinates of globalization changes and euro integration [1]. Some economists, such as Lipkova L., Kovarova E., Navratil B. explore development issues of innovation policy of the European Union and West Africa [5;9;10]. Stanickova M. explores the assessment of efficiency in selected EU member states by data envelopment analysis models [6]. Analysis of the recent scientific materials indicates the results of comprehensive research on the development and implementation of the elements of innovation and investment mechanism, improvement of the investment climate, some economic and statistic calculations. Thus, strategy in actions, strategic control, investment development management, elaboration of economic and financial mechanisms are examined in details. It should be noted that much attention is paid to problems of strategy management processes on the level of country economics and particular industries [1]; the methodological platform of the integrated innovative dominants of strategic control and continuous improvement on the base of the quality and quantity imperative.

\section{PRoblem Description AND the GoAl of THE Work}

The purpose of the paper is to study innovative dominants of strategic control and continuous improvement on the base of the quality and quantity imperative in the coordinates of globalization changes and European integration; analysis and characterization of the strategic control, such as: monitoring strategic thrusts or projects, researching two basic types of implementation control, the develop of customer orientation, systematization examples of ways customer value across business processes in several functions.
Theoretical and methodological basis of the research consist of the research of modern economic concepts of management, informatization, economic and mathematical modelling. The objective of research consists in defining the quality and quantity imperative regarding strategy control.

\section{RESULTS AND DISCUSSION}

The control of strategy can be characterized as a form of "steering control." Ordinarily, a good deal of time elapses between the initial implementation of a strategy and achievement of its intended results. During that time, investments are made and numerous projects and actions are undertaken to implement the strategy. Also, during that time, changes are taking place in both the environmental situation and the firm's internal situation. Strategic controls are necessary to steer the firm through these events. They must provide the basis for adapting the firm's strategic actions and directions in response to these developments and changes.

The methodological basis of the process of strategizing the activation of innovation and investment development of industrial enterprises, the formation of its conceptual model, the implementation of strategic control and components forms the following:

- Budgeting of innovation-investment development of the enterprise as a process of development, implementation, control and analysis of the financial plan of innovation-investment development of the enterprise, covering all parties of innovationinvestment activity and investment design, allow to compare the incurred expenses and the obtained results in the financial terms for the future and individual periods.

- Methodology of management analysis of enterprise innovation and investment activity as a systematic use of traditional and newest methods of financial and economic calculations, which include: investment, financial and investment and marketing analysis, discount method for evaluation of investment projects stages. The totality of their specific types, techniques and methods will constitute the methodological and methodological foundations of the analytical block in the strategy of the innovation and investment development activation of an industrial enterprise.

- Efficiency criteria for the activation of innovation and investment development, covering four poles of strategic management: internal coordination mechanism, incentive procedures, information systems, decision-making structures. The parameters of efficiency are recognized as the most important parameters of the functioning of an industrial enterprise, which must be achieved by the results of innovation and investment development, which allow to assess the quality of development and achievement of its goals stated by the enterprise.

- Administrative method of management, because administration as a process provides a clear division of responsibilities in the management apparatus, compliance with legal norms and powers in resolving issues of economic activity. At the strategic level, 
administration management refers to the process of formation and implementation of the strategy of innovation and investment development, that is, the process of its strategy by methods of controlling processes, procedures, executors.

- Methods of forecasting, programming and modelling pertaining to the methods of development and implementation of administration, but their application in the strategy for activation of innovation and investment development requires the use of more complex scientific and practical tools in the form of derivatives, combined entities consisting of methods of analysis, design, design and development of forms, structures and procedures.

- Economic interpretation of the strategy of activation of innovation and investment development as a system of ensuring the competitive advantages of the enterprise in terms of compliance control and modern instrumental and technological base for modelling the strategy of enterprise development.

The four basic types of strategic control are: premise control, special alert control, strategic surveillance, implementation control.

In the article, the authors show particular interest in the control function. The functional aspect is expressed through a quantitative and qualitative imperative. Modelling the strategy and its further support involves consistent management steps, a certain implementation of strategic programs, investment flows by cumulative methods over a certain period of time. A number of strategic programs are being implemented. At the same time, functions and tasks initiate the development of managerial actions related to the implementation of the strategy. A personnel team is being formed, resources are being calculated. Senior executives implement planning into a specific program of action, quantitatively and qualitatively substantiating strategy and tactics. In practice, strategic control is called implementation control, as process modelling is performed on the market. The objective function of monitoring the implementation is to integrally evaluate the current period and calculate the necessary deviations for the planning period in the light of market changes that optimize the overall strategy.

Scientists of practice distinguish two main types of functional control of realization: monitoring of strategic programs, analysis and optimization of strategy sectors.

Let's start our research with monitoring strategic programs. An integrated strategy is formed through step-bystep strategic programs, which in practice are called narrow strategic projects. These are elements of an overall strategy. The purpose of strategic planning is the correct logical sequence of strategic actions. Managers receive information fragmentally each period of the implementation of the overall strategy and thus see the need for its optimization, clear implementation of planning or deviation from the plan as necessary. The control function is performed during the implementation of individual strategic narrow programs or projects. The disadvantage is that in the early stages it is difficult to assess the overall outcome of the strategy. Since if the development vector there is a deviation from the plan, then the general implementation scheme breaks down and a new optimal narrow project must be wedged. The strategic map for the implementation of the overall strategy involves a bunch of narrow complementary projects and justification of success factors for each of them. The fundamentally opposite action consists in the use of stop-and-run estimates that can be caused by the realities of the business environment (time, costs, staff, innovations, information).

A program of regional development via company-owned inns in the Rocky Mountain area was a monitoring thrust that Days Inn used to test its strategy of becoming a nationwide motel chain. Problems in meeting time targets and unexpectedly large capital needs led Days Inn's executives to abandon the overall strategy and eventually sell the firm [4].

Here is an example of the implementation of the control function for the Boeing product development strategy for entering the market of supersonic vehicles (SST). It is based on a review of the intermediate stages of action, coordination, and optimization. Boeing invested millions of dollars and years of scarce engineering talent during the first phase of its SST project, and competition from the BritishFrench Concord was intense. The company's management calculated the need for high capital investments for the future period. Boeing management has identified a financial fundraising point through external investment, government subsidies and a time frame. The milestone reviews greatly increased the estimates of production costs; predicted relatively few passengers and rising fuel costs, thus raising the estimated operating costs; and noted that the Concorde, unlike Boeing, had the benefit of massive government subsidies. These factors prompted Boeing management to abandon the SST strategy, despite high costs, pride and patriotism [5]. As a result, the strategy has changed its vector of development.

The example illustrates the introduction of a narrow strategy for element-by-element efficiency calculation, when there is a need for redistribution of core resources and additional financing of the investment project. This direction may also arise for a number of other production tasks, especially if the project period is designated as longterm. Economists highlight the so-called key uncertainty and rapid response to its end result in the strategy. In theory, this was called the quantitative and qualitative imperative of solving a narrow strategic problem on a general strategy. It should be noted that such changes can affect the overall period of implementation of the strategy. In this example, the production period increased by two years from the control point. As a result, the main strategic goal of the company was achieved by optimization. The control function of the implementation accompanies the general strategy, calculates possible alternatives, the differential approach for solving the general problem is traced.

The operational control scheme is reflected in Table 1, which illustrates a typical operational control system. The above analytical fragments show a progressive surplus of the five-year general strategy. These calculations allow us to identify the company as a supplier of high-quality products focused on customer service. The main strategic objective of the management is to compare the achieved results with the planned ones. The current estimate deviation is of particular 
interest in achieving maximum financial results, arguing the order and sequence of actions and for making final decisions on changes or adjustments in the company's activities. We also note the fact that in practice such changes are offered by second-level managers, who directly accompany this narrow strategic period.

From Table 1, it appears that the firm is maintaining control of its cost structure. Indeed, it is ahead of schedule on reducing overhead. The firm is well ahead of its delivery cycle target, while slightly below its target service-to-sales personnel ratio. Its product returns look OK, although product performance versus specification is below standard. Sales per employee and expansion of the product line are ahead of schedule. The absenteeism rate in the service area is on target, but the turnover rate is higher than that targeted. Competitors appear to be introducing products more rapidly than expected.

This information presents operations managers with several options. They may attribute the deviations primarily to internal discrepancies. In that case, they can scale priorities up or down. For example, they might place more emphasis on retaining customer service personnel and less emphasis on overhead reduction and new product development. On the other hand, they might decide to continue as planned in the face of increasing competition and to accept or gradually improve the customer service situation.

Another possibility is reformulating the strategy or a component of the strategy in the face of rapidly increasing competition. For example, the firm might decide to emphasize more standardized or lower-priced products to overcome customer service problems and take advantage of an apparently ambitious sales force.

This is but one of many possible interpretations of Table 1. The important point here is the critical need to monitor progress against standards and to give serious in-depth attention to both the causes of observed deviations and the most appropriate responses to them.

Correcting deviations in performance brings the entire management task into focus. Managers can correct such deviations by changing measures or plans. They also can eliminate poor performance by changing how things are done, by hiring or retraining workers, by changing job assignments, and so on. Correcting deviations, therefore, can involve all of the functions, tasks, and responsibilities of operations managers.

Managers in other cultures, most notably Japan, have for some time achieved operational control by seeking their unit's continuous improvement. Companies worldwide have adapted this point of view that operational control is best achieved through a pervasive commitment to quality, originally called total quality management (TQM), which is seen as essential to strategic success into the 21 st century.

TQM is viewed as virtually a new organizational culture and way of thinking. It is built around an intense focus on customer satisfaction; on accurate measurement of every critical variable in a business's operation; on continuous improvement of products, services, and processes; and on work relationships based on trust and teamwork.
TABLE I. MONITORING AND EVALUATING PERFORMANCE DEVIATIONS (calculated by the author on $[6,7,8]$ )

\begin{tabular}{|c|c|c|c|c|c|}
\hline $\begin{array}{c}\text { Key } \\
\text { Success } \\
\text { Factors } \\
\text { Perfor- } \\
\text { mance }\end{array}$ & $\begin{array}{l}\text { Objec- } \\
\text { tive } \\
\text { Assump } \\
\text { tion, or } \\
\text { Budget }\end{array}$ & $\begin{array}{c}\text { Forecast } \\
\text { Perfor- } \\
\text { mance at } \\
\text { This } \\
\text { Time }\end{array}$ & $\begin{array}{l}\text { Cur- } \\
\text { rent } \\
\text { Perfor } \\
\text { mance }\end{array}$ & $\begin{array}{l}\text { Curre } \\
\text { nt } \\
\text { Devi- } \\
\text { ations }\end{array}$ & Analysis \\
\hline $\begin{array}{l}\text { Cost } \\
\text { control: } \\
\text { Ratio of } \\
\text { indirect } \\
\text { overhead } \\
\text { cost to } \\
\text { direct } \\
\text { field and } \\
\text { labour costs } \\
\end{array}$ & $10.0 \%$ & $18.0 \%$ & $11.0 \%$ & $\begin{array}{l}+7.0 \% \\
\text { (ahead) }\end{array}$ & $\begin{array}{l}\text { Are we } \\
\text { moving too } \\
\text { fast, or is } \\
\text { there more } \\
\text { unnecessary } \\
\text { overhead } \\
\text { than was } \\
\text { originally } \\
\text { thought? }\end{array}$ \\
\hline Gross profit & $39.0 \%$ & $42.0 \%$ & $42.0 \%$ & $0.0 \%$ & - \\
\hline $\begin{array}{l}\text { Customer } \\
\text { service: } \\
\text { Installation } \\
\text { cycle in } \\
\text { days }\end{array}$ & 2.5 days & 3.5 days & $\begin{array}{l}2.8 \\
\text { days }\end{array}$ & $\begin{array}{l}+0.7 \\
\text { (ahead) }\end{array}$ & $\begin{array}{l}\text { Can this } \\
\text { progress be } \\
\text { maintained? }\end{array}$ \\
\hline $\begin{array}{ll}\begin{array}{l}\text { Ratio of } \\
\text { service }\end{array} & \text { to } \\
\text { sales } & \\
\text { personal } & \end{array}$ & 3.0 & 2.8 & 2.1 & $\begin{array}{c}-0.7 \\
\text { (behind) }\end{array}$ & $\begin{array}{l}\text { Why are we } \\
\text { behind here? } \\
\text { How can we } \\
\text { maintain the } \\
\text { installation- } \\
\text { cycle } \\
\text { progress? }\end{array}$ \\
\hline $\begin{array}{l}\text { Product } \\
\text { quality: } \\
\text { percentage } \\
\text { of } \\
\text { products } 1.0 \\
\% \\
\text { returned }\end{array}$ & $1.0 \%$ & $2.0 \%$ & $2.2 \%$ & $\begin{array}{c}-0.2 \\
\text { (behind) }\end{array}$ & $\begin{array}{l}\text { Why are we } \\
\text { behind here? } \\
\text { What are the } \\
\text { ramifica- } \\
\text { tions for } \\
\text { other } \\
\text { operations? }\end{array}$ \\
\hline $\begin{array}{l}\text { Product } \\
\text { perfor- } \\
\text { mance } \\
\text { versus } \\
\text { specifi- } \\
\text { cation }\end{array}$ & $100.0 \%$ & $93.0 \%$ & $81.0 \%$ & $\begin{array}{l}-12.0 \% \\
\text { (behind) }\end{array}$ & - \\
\hline $\begin{array}{l}\text { Marketing: } \\
\text { Monthly sales } \\
\text { per employee }\end{array}$ & $\$ 12.50$ & $\$ 12.50$ & $\$ 12.10$ & $\begin{array}{l}+\$ 400 \\
\text { (ahead) }\end{array}$ & $\begin{array}{l}\text { Good } \\
\text { progres. Is it } \\
\text { creating any } \\
\text { problems to } \\
\text { support? }\end{array}$ \\
\hline $\begin{array}{l}\text { Expansion } \\
\text { of product } \\
\text { line }\end{array}$ & 6 & 3 & 5 & $\begin{array}{c}+2 \\
\text { products } \\
\text { (ahead) }\end{array}$ & $\begin{array}{l}\text { Are the } \\
\text { products } \\
\text { ready? Are } \\
\text { the perfect } \\
\text { standards } \\
\text { met? }\end{array}$ \\
\hline $\begin{array}{l}\text { Emploee } \\
\text { morale in } \\
\text { service } \\
\text { area: } \\
\text { Absente- } \\
\text { eism rate } \\
\text { Turnover } \\
\text { rate }\end{array}$ & $\begin{array}{l}2.5 \% \\
5.0 \%\end{array}$ & $\begin{array}{l}3.0 \% \\
10.0 \%\end{array}$ & $\begin{array}{l}3.0 \% \\
15.0 \%\end{array}$ & \begin{tabular}{l}
\multicolumn{1}{c}{ (on } \\
target) \\
$-8.0 \%$ \\
(behind)
\end{tabular} & $\begin{array}{l}\text { Looks like a } \\
\text { problem! } \\
\text { Why are we } \\
\text { sofar } \\
\text { behind? }\end{array}$ \\
\hline $\begin{array}{l}\text { Compe- } \\
\text { tition: } \\
\text { New } \\
\text { product } \\
\text { Introduce- } \\
\text { tions } \\
\text { (average } \\
\text { number) } \\
\end{array}$ & 5 & 3 & 7 & $\begin{array}{c}-4 \\
\text { (behind) }\end{array}$ & $\begin{array}{l}\text { Did we } \\
\text { underestimat } \\
\text { e timing? } \\
\text { What are the } \\
\text { implications } \\
\text { for } \\
\text { our basic } \\
\text { assumptions? }\end{array}$ \\
\hline
\end{tabular}

One useful explanation of the quality imperative suggests 10 essential elements of implementing total quality management, as follows: define quality and customer value, develop a customer orientation, focus on the company's business processes, develop customer and supplier 
partnerships, take a preventive approach, adopt an error-free attitude, get the facts first, encourage every manager and employee to participate, create an atmosphere of total involvement, strive for continuous improvement [5;9].

Figure 1 has demonstrated the development of customer orientation.

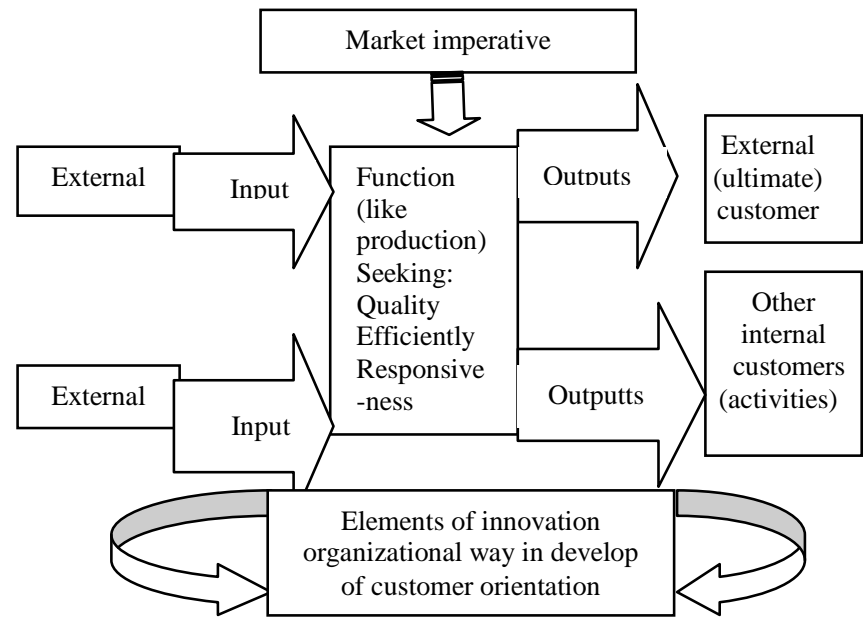

Fig.1. Develop of customer orientation: market imperative (improved by the authors)

Rather than be left to individual interpretation, company personnel should have a clear definition of what quality means in the job, department, and throughout the company. It should be developed from your customer's perspective and communicated as a written policy. Examples of ways customer value is enhanced across business processes in several functions are systematized in the Table 2 .

In the process of modelling strategies on the foreign market, to assess the majority of financial decisions, one has to deal with multiple cash flows, with cash payments or receipts occurring over a number of time intervals. As an example, you can consider acquiring securities for which periodic interest payments are expected. Elements of the flow can be either independent or interconnected by a certain algorithm. Temporary periods are most often assumed to be equal. It is also believed that the receipts generated within the same time period take place either at its beginning or at its end, that is, they are not distributed within the period, but are concentrated on one of its borders. If cash receipts take place at the beginning of a time period, then such a stream is called a prenumerando stream, or advance, and if at the end of a postnumerando. In practice and, in particular, when evaluating investment projects, the flow of postnumerando has become more widespread. The cash flow assessment can be carried out within the framework of solving two problems:

- direct, i.e., an assessment is made from the perspective of the future (an accumulation scheme is being implemented);

- the inverse, i.e., an assessment is made from the position of the present (a discounting scheme is being implemented).
TABLE II. EXAMPLES OF WAYS CUSTOMER VALUE IS ENHANCED ACROSS BUSINESS PROCESSES IN SEVERAL FUNCTIONS (systematized by the authors on the $[10,11,12])$

\begin{tabular}{|c|c|c|c|}
\hline Function & Quality & Efficiency & Responsiveness \\
\hline Marketing & $\begin{array}{l}\text { Provides } \\
\text { accurate } \\
\text { assessment of } \\
\text { customer's } \\
\text { product } \\
\text { preferences to } \\
\text { R\&D }\end{array}$ & $\begin{array}{l}\text { Consumer } \\
\text { properties of } \\
\text { goods form } \\
\text { production }\end{array}$ & Market imperative \\
\hline $\begin{array}{l}\text { Operations } \\
\text { and } \\
\text { organisation }\end{array}$ & $\begin{array}{l}\text { Production of } \\
\text { fashionable } \\
\text { products that } \\
\text { are useful to } \\
\text { the consumer }\end{array}$ & $\begin{array}{l}\text { Minimizes } \\
\text { scrap and } \\
\text { rework } \\
\text { through high- } \\
\text { production } \\
\text { yield }\end{array}$ & $\begin{array}{l}\text { Quickly adapts to } \\
\text { latest demands with } \\
\text { production } \\
\text { flexibility }\end{array}$ \\
\hline $\begin{array}{l}\text { Research } \\
\text { and } \\
\text { development }\end{array}$ & $\begin{array}{l}\text { Designs } \\
\text { products that } \\
\text { combine } \\
\text { customer } \\
\text { demand and } \\
\text { production } \\
\text { capabilities }\end{array}$ & $\begin{array}{l}\text { Uses } \\
\text { computers to } \\
\text { test feasibility } \\
\text { of idea before } \\
\text { going to more } \\
\text { expensive full- } \\
\text { scale prototype }\end{array}$ & $\begin{array}{l}\text { Carries out parallel } \\
\text { product/process } \\
\text { designs to speed up } \\
\text { overall innovation }\end{array}$ \\
\hline $\begin{array}{l}\text { Accounting } \\
\text { and financial }\end{array}$ & $\begin{array}{l}\text { Provides } \\
\text { the } \\
\text { information } \\
\text { that } \\
\text { managers } \\
\text { in other } \\
\text { functions } \\
\text { need to } \\
\text { make } \\
\text { decisions }\end{array}$ & $\begin{array}{l}\text { Simplifies and } \\
\text { computerizes } \\
\text { to decrease the } \\
\text { cost of } \\
\text { gathering } \\
\text { information }\end{array}$ & $\begin{array}{l}\text { Provides } \\
\text { information in "real } \\
\text { time" (as the events } \\
\text { described are still } \\
\text { happening), } \\
\text { substantiation of } \\
\text { financial position }\end{array}$ \\
\hline Purchasing & $\begin{array}{l}\text { Selects vendors } \\
\text { for their ability } \\
\text { to join in an } \\
\text { effective } \\
\text { "partnership" }\end{array}$ & $\begin{array}{l}\text { Given the } \\
\text { required vendor } \\
\text { quality, } \\
\text { negotiates } \\
\text { prices to } \\
\text { provide good } \\
\text { value }\end{array}$ & $\begin{array}{l}\text { Schedules inbound } \\
\text { deliveries } \\
\text { efficiently, avoiding } \\
\text { both extensive } \\
\text { inventories and } \\
\text { stock-outs }\end{array}$ \\
\hline $\begin{array}{l}\text { Personnel } \\
\text { and team } \\
\text { building }\end{array}$ & $\begin{array}{l}\text { Trains } \\
\text { workforce } \\
\text { to perform } \\
\text { required } \\
\text { tasks } \\
\end{array}$ & $\begin{array}{l}\text { Minimizes } \\
\text { employee } \\
\text { turnover, work } \\
\text { in teams }\end{array}$ & $\begin{array}{l}\text { In response to } \\
\text { strong growth in } \\
\text { sales, finds large } \\
\text { numbers of } \\
\text { employees, }\end{array}$ \\
\hline
\end{tabular}

Time periods are most often assumed to be equal. If cash proceeds occur at the beginning of the interim period, such a flow is called a prenumerando stream, or an advance stream, and if at the end of the postnumerantno. The quality and quantity imperative or the direct task involves a total assessment of the accumulated cash flow, so it is based on future value. In particular, if the cash flow is a regular accrual of interest on invested capital (C) according to the compound interest scheme, then the following formula is the basis for the total assessment of the accumulated cash flow:

$$
F V=\sum_{k=1}^{n} C_{k} \times(1+i)^{k}
$$

where:

$$
\begin{aligned}
& F V \text { - future value of money; } \\
& i \text { - interest rate; } \\
& k \text { - time interval. }
\end{aligned}
$$




\section{CONCLUSIONS AND PROPOSALS}

Tree fundamental perspectives, such as, strategic control, continuous improvement, and the balanced scoreboard, provide the basis for designing strategy control systems [3].

The tool for the implementation of systemic actions of operational control is the quantitative and qualitative imperative of the strategic process. At the same time, an efficiency assessment is formed according to the standards of the economic system as a whole. The emerging deviations in the implementation of the strategy are aimed at increasing the final effect. The main task is to identify such deviations and argue for changes in the implementation of the strategy. A circle of possible consequences is determined, the influence of external and internal factors, a forecast of expected results is provided. We also stipulate the fact that there is predictive validity, which analytically substantiates specific changes in actions for a certain period. At the same time, many companies formulate narrow strategic plans for a number of emergency situations. The ultimate integral goal is to obtain the expected profit with possible market requirements.

The "quality imperative" of the last 20 years has redefined global competitiveness to include reshaping the way many businesses approach strategic and operational control. What has emerged is a commitment to continuous improvement in which personnel across all levels in an organization define customer value, identify ways every process within the business influences customer value, and seek continuously to enhance the quality, efficiency, and responsiveness with which the processes, products, and services are created and supplied [3;7]. So, summing up the line under consideration of applied strategic control as a relatively new tool of strategic corporate management, it should be noted that applied strategic analysis:

- involves a comprehensive, integrated study of the strategic aspects of the organization's economic activities which is based on a balanced scorecard;

- can not have a standard methodology, but only a general methodology without any universal concretization of it;

- aims to form analytical support for the adoption of strategic management decisions;

- consists of assessing, diagnosing and forecasting the values of indicators of the strategic indicators system in the strategic, tactical and operational aspects;

- has four main areas: analysis of financial indicators, analysis of client indicators, analysis of internal business processes indicators and indicators analysis of personnel training and development. It includes more private components in;

- begins with a comparative assessment of financial indicators and ends with the forecasting of indicators for staff training and development $[3 ; 12]$.

At the end, this study provides the methodological platform of the integrated innovative dominants strategic control and continuous improvement on the base of the quality and quantity imperative. Results of research can be used for acceptance of justified managerial decisions of strategy development of enterprises, administrative tracking of functioning of the organisation.

\section{ACKNOWLEDGEMENT}

The scientific and methodical tools have been implemented: by the Executive Committee of the Odessa City Council in the form of "Scientific and methodological recommendations to local authorities regarding the evaluation of the effectiveness of investment projects under the conditions of compliance control (certificate No. 12.2-16 outgoing number / 890 dated December 6, 2016, Act No. 21 / 01-12 / D dated September 1, 2016); Department of Economic Development of Odessa City Council (certificate No. 2565 / 01-41 dated December 5, 2016) during the development of the Strategy of Economic and Social Development of Odessa City until 2022, Program of SocioEconomic and Cultural Development of Odessa City in 2020, Investment Strategy "Odessa 5T".

\section{REFERENCES}

[1] L. Karpenko, P., and Voronzhak, "Base alternatives and the paradigm of impact investing development in the coordinates of globalization changes and euro integration". In: Proceedings of the 4th International Conference on European Integration 2018. Ostrava: VSB Technical University of Ostrava, 2018, pp.659-668.

[2] N. Ilysheva, and S. Krylova, "Accounting, Analysis and Strategic Management of Innovation Activity". Moscow: Finances \& Statistics, 2014.

[3] J. Elton Edvin, J. Gruber Martin, J. Brown Stephen, and N. William Goetzmann, "Modern Portfolio. Theory and Investment Analysis", 7th Edition. - USA: New York: Hamilton Printing Company, 2014

[4] J. Frank Fabozzi, CFA, "Investment management", 2nd ed. - USA, New Jersey: Prentice-Hall, Inc., 2008.

[5] L. Lipkova, "Innovation Policy of the European Union". In Honova, I., L.Melecky and M.Stanickova (ed). Proceeding of the $1^{\text {st }}$ International Conference on European Integration 2012. Ostrava: VSB-Technical University of Ostrava, 2012, pp. 171-178.

[6] M. Stanickova, "Assessment of Efficiency in Selected EU Member States by Data Envelopment Analysis Models". In Honova, I., L.Melecky and M.Stanickova (ed). Proceeding of the $1^{\text {st }}$ International Conference on European Integration 2012. Ostrava: VSB-Technical University of Ostrava, 2012, pp. 303-314.

[7] A. John Pearce, "Strategic management: formulation, implementation and control", 8th ed. - USA, New Jersey: Publications Office of the McGraw-Hill Companies, 2013

[8] L.Karpenko, P. Pashko, P.Voronzhak, H. Kalach, and M. Nazarov, "Formation of the system of fair businesspractice of the company under conditions of corporate responsibility", Academy of Strategic Management Journal, vol.18, no 2, pp.1-8, 2018.

[9] B. Navratil, "Ever-Coser or Multi-Speed Union". In Kovarova, E., L.Melecky and M.Stanickova (ed). In Proceeding of the $3^{\text {st }}$ International Conference on European Intergration 2016. Ostrava: VSB-Technical University of Ostrava, 2016, pp. 649-655.

[10] E. Kovarova, "Value and Commodity Structure of the West Africa's Exports to the European Union". In Kovarova, E., L.Melecky and M.Stanickova (ed). In Proceeding of the $3^{\text {st }}$ International Conference on European Intergration 2016. Ostrava: VSB-Technical University of Ostrava, 2016, pp. 480-488.

[11] S. Frankova, "Instruments for Innovation Support and Their Classification: an Example of Instruments used in European Countries". In Kovarova, E., L.Melecky and M.Stanickova (ed). In Proceeding of the $3^{\text {st }}$ International Conference on European Intergration 2016. Ostrava: VSB-Technical University of Ostrava, 2016, pp. 649-655.

[12] R. Casidy, "Linking Brand Orientation with Service Quality, Satisfaction, and Positive Word-of-Mouth: Evidence from the Higher Education Sector", Journal of Nonprofit and Public Sector Marketing, vol. 26, no 2, pp. 142-161, 2014 